\title{
Tissue Distribution and Molecular Profile of a Differentiation Antigen Detected by a Monoclonal Antibody (345.134S) Produced Against Human Melanoma Cells*
}

\author{
Kohzoh Imai $^{1 *}$, Pier G. Natali ${ }^{2}$, Neil E. Kay ${ }^{1 * *}$, Barry S. Wilson ${ }^{1 * * *}$, and Soldano Ferrone ${ }^{1}$ \\ ${ }^{1}$ Department of Pathology, College of Physicians and Surgeons, Columbia University, \\ 630 West 168th Street, New York, NY 10032, USA \\ ${ }^{2}$ Regina Cancer Institute, Rome, Italy
}

Summary. The mouse IgG2a monoclonal antibody (MoAb) 345.134S, secreted by a hybridoma derived from a mouse immunized with cultured human melanoma cells, reacts with an 85,000-dalton glycopolypeptide which is disulfide-bridged to a 30,000-dalton polypeptide having little if any covalently attached carbohydrate. The 115,000-dalton complex is peripheral rather than integral in its association with the plasma cell membrane. Indirect immunofluorescence of cryostat thin sections of human tissues with the $M o A b$ 345.134S showed (1) strong staining of the sebaceous glands and basal layer of normal hyperpigmented skin; (2) weak staining of the basal layer of normal pigmented skin and epithelial cells of the gastrointestinal tract, parotid, renal proximal tubules, thyroid, and urinary bladder; and (3) no staining of melanocytes, mammary gland, lung, brain cortex, or liver. The staining pattern of tissues from a 20-week-old fetus is similar to that of tissues from adults. The MoAb 345.134S stained some cases of virtually all tumors tested, including some derived from normal tissues non-reactive with the antibody; intensity of staining of tumors was in general much greater than in normal tissues. The expression of the antigen detected by MoAb 345.134S in a panel of cultured human tumor cells did not correlate with the expression of other tumor-associated antigens or with

Reprint requests should be addressed to $\mathrm{S}$. Ferrone

* Present address: Department of Internal Medicine, Sapporo Medical College, Japan

** Present address: Veterans Administration Hospital, Minneapolis, Minnesota, USA

*** Present address: Department of Pathology, University of Michigan Medical School, Ann Arbor, MI, USA

Abbreviations used: MAA, melanoma-associated antigens; MoAb, Monoclonal antibody; $\beta_{2}-\mu, \beta_{2}$-microglobulin; $\mathrm{PBL}$, peripheral blood lymphocytes; IIF, indirect immunofluoresence; SDS-PAGE, sodium dodecyl sulfate polyacrylamide gel electrophoresis; NP40, nonidet P40; ADCC, antibody-dependent cell-mediated cytotoxicity
$H L A-A, B$ or Ia-like antigens. The MoAb $345.134 S$ can mediate complement- and cell-dependent lysis of cultured human tumor cells. The lack of correlation between the extent of immune lysis and the expression of the antigen detected by MoAb 345.134S as well as the effect of puromycin on antibody-mediated cell-dependent lysis indicated that factors other than antigen density play a significant role in the outcome of immune lytic reactions mediated by this monoclonal antibody.

\section{Introduction}

The production of monoclonal antibodies has greatly facilitated the analysis of the antigenic profile of human tumor cells. These studies will eventually identify markers that will be useful in the development of immunodiagnostic and immunotherapeutic approaches to malignant diseases and will contribute to our understanding of the abnormal behavior of tumor cells. Monoclonal antibodies have been extensively applied in the analysis of human melanoma cells, and through the efforts of several investigators a variety of antigens have been identified which are expressed by melanoma cells $[5,6,9-11,16,22,29$, 31] but are not detectable on melanocytes $[6,9,22$, 29, 31]; these antigens are referred to as melanoma-associated antigens (MAA). We have developed several monoclonal antibodies to human melanoma cells; in previous studies we have analyzed monoclonal antibodies to a high-molecular-weight plasma membrane-bound MAA and to a cytoplasmic MAA $[22,29]$. In this study we characterize the MoAb 345.134 S, which defines a membrane-bound glycoprotein with serological and structural properties distinct from those of other membrane-bound glycoproteins identified on human melanoma cells with monoclonal antibodies. Specifically, we will describe: 
(1) the structure of the target antigen; (2) the distribution of the antigen in normal and malignant tissues; and (3) the expression of the antigen on cultured cells and its ability to function as a target of immune lysis.

\section{Materials and Methods}

Preparation of Monoclonal Antibodies (MoAb). Splenocytes from a BALB/c mouse immunized with cultured melanoma cells Colo38 were fused with the murine myeloma line $\mathrm{Sp} 2 / 0-\mathrm{Ag} 14$ according to the hybridoma procedure described elsewhere $[10,11]$. The hybridoma secreting MoAb 345.134S, selected by its strong reactivity with a panel of cultured cells, has been subcloned twice and has been propagated in vitro and in vivo for at least 1 year. Immunodiffusion analysis with rabbit anti-mouse Ig antisera (Litton Bionetics, Kensington, MD, USA) has shown that the MoAb 345.1345 is of the IgG2a subclass. The monoclonal antibodies Q5/13 to human Ia-like antigens [25], NAMB-1 to human $\beta_{2}$-microglobulin $\left(\beta_{2}-\mu\right)$ [23], 225.28S to a high-molecular-weight MAA [29], and $376.96 \mathrm{~S}$ to a $94 \mathrm{~K}$ tumor-associated antigen [30] have been described in the indicated references. The MoAb W6/32 reactive with the heavy chain of HLA-A,B,C antigens [24] was obtained commercially (Accurate Chemical Co., Hicksville, NY USA).

Human Cells. Cells in long-term culture were maintained in RPMI 1640 medium containing $10 \%$ calf serum. Peripheral blood lymphocytes (PBL) and leukemic cells were isolated from heparinized blood by differential centrifugation on Ficoll-Hypaque and then separated into $\mathrm{T}$ and $\mathrm{B}$ cell populations by nylon wool filtration [14]. Peripheral blood monocytes were obtained by adherence to plastic in a T75 flask (Falcon Plastics, Cockeysville, $\mathrm{MD}, \mathrm{USA}$ ) at $37^{\circ} \mathrm{C}$ for $30 \mathrm{~min}$ [14]. Granulocytes were prepared from heparinized blood as described by Boyum [3].

Melanoma cells in log phase $\left(5 \times 10^{5} / \mathrm{ml}\right)$ were cultured with $500-2,000 \mathrm{IU} / \mathrm{ml}$ partially purified human leukocyte interferon (a generous gift of Dr. K. Cantell, Central Public Health Center, Helsinki, Finland) or with $1-5 \mu \mathrm{g}$ puromycin/ml (Sigma, St. Louis, MO, USA) for $16 \mathrm{~h}$ at $37^{\circ} \mathrm{C}$. The cells were then washed three times with minimum essential medium and then used in the antibody-dependent cell-mediated cytotoxicity (ADCC) assay. The interferon treatment did not affect cell viability or growth, and the effect of puromycin on protein synthesis was monitored by incorporation of ${ }^{3} \mathrm{H}$-proline.

Tissue Specimens. Tissues were obtained surgically from untreated patients and from patients undergoing different therapeutic regimens. Normal tissues were obtained from surgically removed neoplastic lesions. Tissue specimens were snap-frozen in liquid nitrogen and two consecutive cryostat sections of $4 \mu$ thickness were obtained from each frozen tissue: one section was stained with toluidine blue $(0.1 \%$ in phosphate-buffered saline), while the other was fixed for $10 \mathrm{~min}$ in cold absolute acetone and then used in the indirect immunofluorescence (IIF) test. Absolute acetone was chosen over other fixatives because it retained the most detail after fluorescent staining.

Radiolabelling, Indirect Immunoprecipitation and Sodium Dodecyl Sulfate Polyacrylamide Gel Electrophoresis (SDS-PAGE). Human melanoma cells were intrinsically radiolabelled with ${ }^{3} \mathrm{H}$-glucosamine D- $\left[6-{ }^{3} \mathrm{H}(\mathrm{N})\right] 30 \mathrm{mCi} / \mathrm{mmole}$ (New England Nuclear, Boston, MA, USA) according to the method of Duksin and Bornstein [7] or were surface-labelled with ${ }^{125} \mathrm{I}$ (Amersham, Arlington
Heights IL, USA) by the Iodogen method of Salisbury and Graham [27]. Labelled cells were extracted with 10 volumes of nonidet P40 detergent (1.0\% in phosphate-buffered saline) containing $10 \mu \mathrm{m}$ phenylmethylsulfonylfluoride by rotation for $30 \mathrm{~min}$ at $4^{\circ} \mathrm{C}$. The extract was cleared by centrifugation at $7,000 \mathrm{~g}$ and stored at $-20^{\circ} \mathrm{C}$. Cell extracts performed with $3 \mathrm{M} \mathrm{KCl}$ or with urea were performed as described for NP40 and dialyzed against phosphate-buffered saline prior to use. Indirect immunoprecipitation was performed as described previously [1], except that protein A-Sepharose 4B (Pharmacia) was used in place of the formalin-fixed bacteria, and pre-clearing of the NP40 detergent cell extract was not necessary. Briefly, $10 \mu \mathrm{l}$ packed protein A Sepharose was mixed with $5 \times 10^{6} \mathrm{cpm}{ }^{125} \mathrm{I}$-labelled cell extract and diluted to $0.5 \mathrm{ml}$ with NET buffer ( $50 \mathrm{~m} M$ Tris, $150 \mathrm{mM} \mathrm{NaCl}$, $5 \mathrm{~m} M$ EDTA, $1 \mathrm{mg}$ bovine serum albumin $/ \mathrm{ml}, \mathrm{pH}$ 7.4). After rotation for $2 \mathrm{~h}$ at $4^{\circ} \mathrm{C}$, the Sepharose was washed eight times with NET buffer and then twice with phosphate-buffered saline. SDS sample buffer was added (100 $\mu$ l) [18] and the Sepharose was boiled at $100^{\circ} \mathrm{C}$ for $2 \mathrm{~min}$ prior to loading on an SDS-polyacrylamide gel. SDS-PAGE was performed in $80 \times 1.5 \mathrm{~mm}$ slab gels containing an acrylamide gradient of $5 \%-12.5 \%$ and the SDS buffer system of Laemmli [18]. The gels containing ${ }^{3} \mathrm{H}$-glucosamine-labelled antigens were processed for fluorography as described by Bonner and Laskey [2] while ${ }^{125}$ I-labelled antigens were autoradiographed at $-70^{\circ} \mathrm{C}$. Rabbit phosporylase a $(94,000)$, bovine serum albumin $(68,000)$, ovalbumin $(44,000)$, carbonic anhydrase $(29,000)$, and whale myoglobin $(17,000)$ were used as molecular weight standards.

Binding Assays and Cell- and Complement-dependent Cytotoxicity Assays. The IIF test was performed by a standard procedure described previously [21]. A distinct bright green fluorescent staining of the plasma membrane was used as a criterion of positive reactions of tissue sections with monoclonal antibodies. Unreactive tissue sections were tested further with concentrated $(20 \mu \mathrm{g} / \mathrm{ml})$ and diluted $(0.5 \mu \mathrm{g} / \mathrm{ml})$ solutions of the monoclonal antibody to avoid false-negative reactions attributable to either a low concentration of the monoclonal antibody or to a prozone-like effect [19]. The specificity of fluorescent staining was controlled by testing tissue sections with myeloma protein secreted by the murine myeloma cells P3-X63-Ag8 or with culture supernatants of the hybridomas $345.134 \mathrm{~S}$ from which the monoclonal antibodies had been removed by adsorption at $4^{\circ} \mathrm{C}$ with one volume of cultured human melanoma cells (M10). The efficiency of adsorption was confirmed by the failure of the adsorbed culture supernatant to stain cultured human melanoma cells.

The ${ }^{125} \mathrm{I}$-SpA radioimmunometric assay was performed in microtiter plates as described elsewhere [23]. The complement-dependent microcytotoxic test was performed as an eosin exclusion test, rabbit serum being used as the complement source [8].

The ADCC assay was performed in 96-well microtiter plates (Cooke Laboratory Products, Alexandria, VA, USA) as described previously [13]. The percentage of specific ${ }^{51} \mathrm{Cr}$ release from the cells was used as a measure of lysis and was calculated as follows:

$$
\% \mathrm{ADCC}=\frac{(\mathrm{A}-\mathrm{B})-(\mathrm{C}-\mathrm{B})}{(\mathrm{T}-\mathrm{B})-(\mathrm{C}-\mathrm{B})} \times 100
$$

where $\mathrm{A}=$ mean cpm of test samples, $\mathrm{B}=$ mean cpm of counter background, $\mathrm{C}=$ mean $\mathrm{cpm}$ of antibody free control in the presence of effector cells, and $\mathrm{T}=$ mean $\mathrm{cpm}$ of total amount of ${ }^{51} \mathrm{Cr}$ incorporated into the target cells. All test combinations were performed in triplicate with spontaneous or background leakage of ${ }^{51} \mathrm{Cr}$ from the target cells ranging from $13 \%$ to $21 \%$ of the total incorporated radiolabel. 
Fig. 1. Immunoprecipitation and SDS-PAGE analysis of the antigenic structures detected by MoAb 345.134S. NP40 extracts of

${ }^{3} \mathrm{H}$-glucosamine-labelled or ${ }^{125}$ Iodine surface-labelled Colo 38 melanoma cells were immunoprecipitated with MoAb $345.134 \mathrm{~S}$ bound to Sepharose $4 \mathrm{~B}$. The labelled antigens were eluted with SDS sample buffer either with or without 2\% 2-mercaptoethanol and then electrophoresed on an SDS-polyacrylamide slab gel. The gel was processed by fluorography and then exposed to Kodak XR-OMAT film

\section{Results}

Structural Profile of the Antigen Identified by the MoAb 345.134S

Indirect immunoprecipitation of an NP40 extract of ${ }^{3} \mathrm{H}$-glucosamine-labelled melanoma cells $\mathrm{Bw} 5$ and Colo38 with the MoAb 345.134S and SDS-PAGE analysis under reducing conditions ( $2 \%$ 2-mercaptoethanol) revealed a major component with the apparent molecular weight of 85,000 (85K) daltons and a minor component of $115 \mathrm{~K}$ daltons (Fig. 1). In contrast, when the immunoprecipitate was electrophoresed under non-reducing conditions, only a single molecule of $115 \mathrm{~K}$ daltons was observed. Indirect immunoprecipitation of NP40 extracts of ${ }^{125}$ I-surface-labelled melanoma cells Colo38 with the $\mathrm{MoAb} 345.134 \mathrm{~S}$ and SDS-PAGE analysis under reducing conditions showed two components, one with the apparent molecular weight of $85 \mathrm{~K}$ daltons and the other one with the apparent molecular weight of $30 \mathrm{~K}$ daltons. When the immunoprecipitate was electrophoresed under non-reducing conditions, the $30 \mathrm{~K}$-dalton molecule and most of the $85 \mathrm{~K}$-dalton molecules disappeared and a new structure was seen, with the approximate molecular weight of $115 \mathrm{~K}$ daltons. Similar SDS-PAGE results were seen with the prostate carcinoma cells $\mathrm{H} 494$ and $\mathrm{Du} 145$ (data not shown). Thus, these results indicate that the structure detected by the monoclonal antibody is composed of an 85K-dalton glycopolypeptide linked by disulfide bridges with a $30 \mathrm{~K}$-dalton polypeptide carrying little or no carbohydrate.

This $115 \mathrm{~K}$-dalton antigen appears to be peripheral rather than integral to the plasma membrane

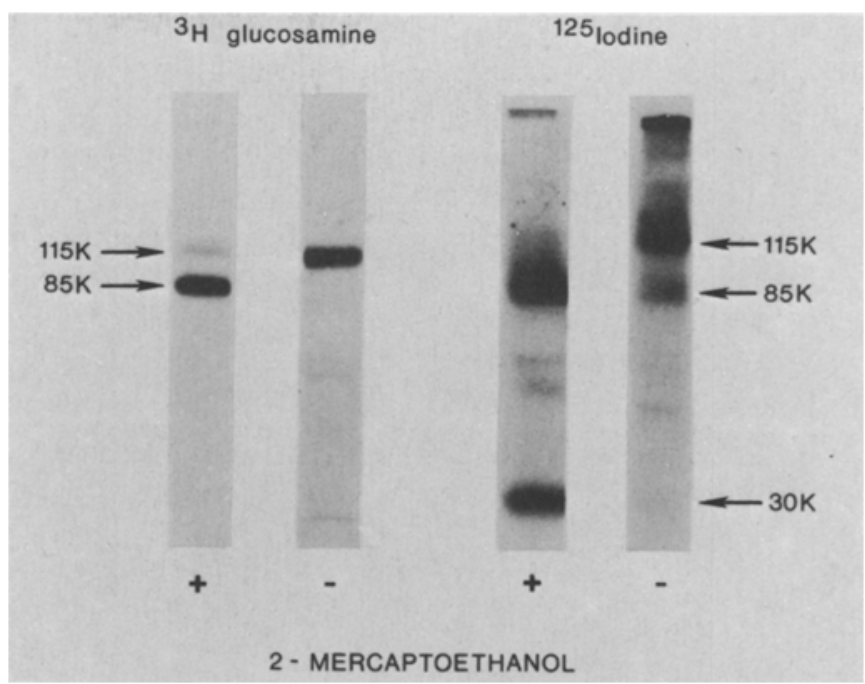

since it is readily solubilized under mildly denaturing conditions ( $10 \mathrm{mM}$ phosphate buffer, $3 \mathrm{M} \mathrm{KCl}, 0.1 \mathrm{M}$ urea) and in the absence of detergents (data not shown).

\section{Reactivity of MoAb 345.134S with Surgically Removed Normal and Malignant Tissues and with Hematopoietic Cells}

Representative patterns of IIF staining of four cryostat sections of surgically removed tissues with the MoAb 345.134S are shown in Figs. 2 and 3. The results have been organized in Table 1 by using the criterion of whether normal tissues are reactive or unreactive with the monoclonal antibody. The following points are noteworthy: (a) the reactivity pattern of normal tissues with the MoAb 345.134S does not correlate with their embryological origin; (b) the majority of positive normal tissues gave a weak staining which could be detected only by examining tissue sections with an oil immersion objective, except for the plasma membrane of the epithelium of sebaceous glands (Fig. 2) and the basal layer of hyperpigmented skin (i.e., mammary areola and perineum), both of which were brightly stained. It should be noted that the weak fluorescence is specific since no staining occurred when the antibody solution was absorbed with cultured melanoma cells. Normal pigmented skin showed faint staining in limited areas of the basal cell layer. The nature of the cells in the basal cell layer was not identified; these cells are not likely to be melanocytes since the MoAb $345.134 \mathrm{~S}$ did not stain melanocytes in other areas of skin from either Negro or Caucasian donors; (c) in 

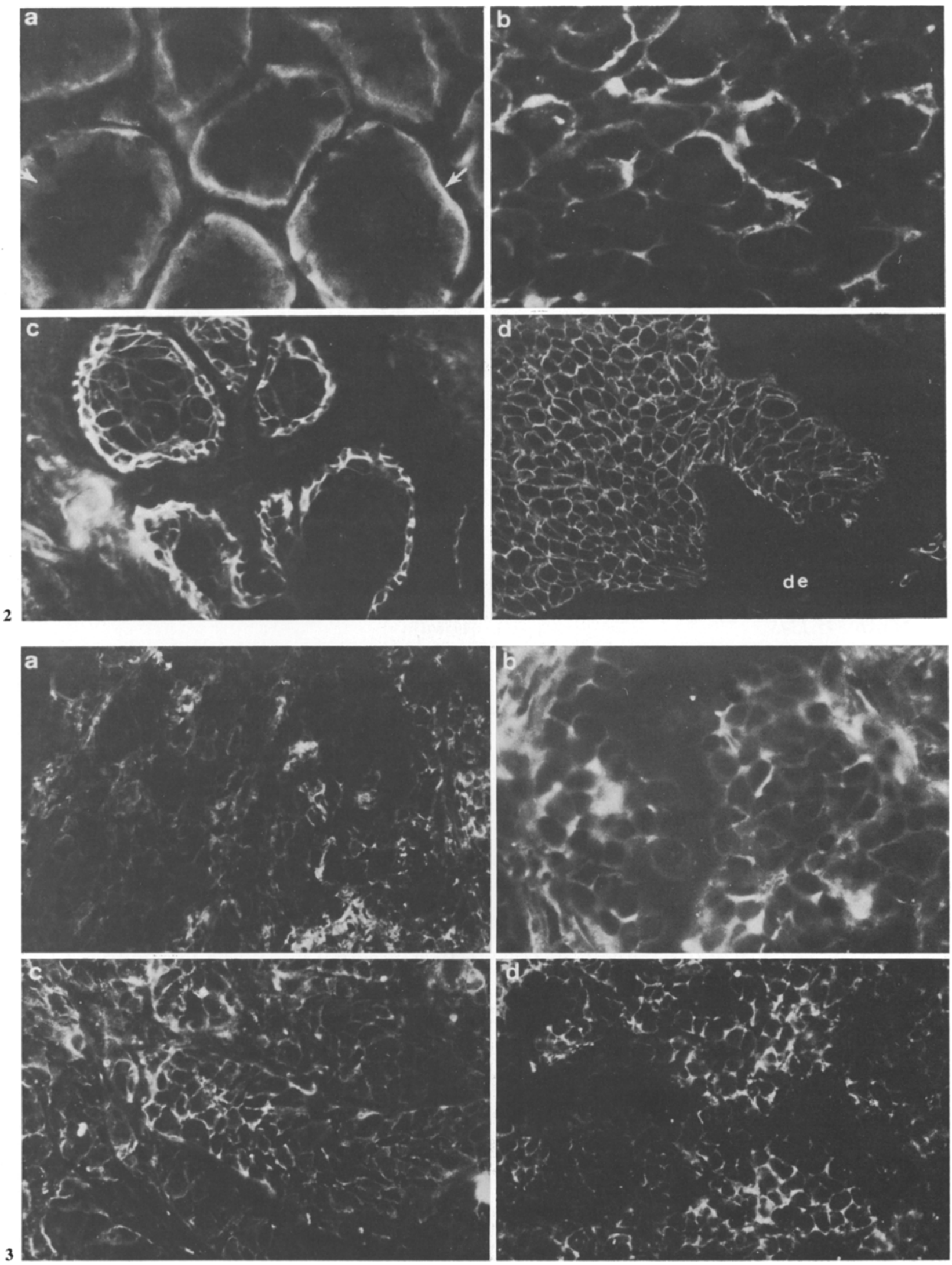

Fig. 2. a-d Indirect immunofluorescence with the $\mathrm{MoAb} 345.134 \mathrm{~S}$ on cryostat sections of adult kidney proximal tubules (a), kidney papillary adenocarcinoma (b), adult skin sebaceous glands (c), and skin squamous cell carcinoma (d). The arrow (a) shows staining of the basal portion of the cytoplasm of tubular epithelial cells; de (d) refers to dermis. a $\times 640 ; \mathbf{b} \times 1,000$; $\mathbf{c}$ and $\mathbf{d} \times 400$

Fig. 3. a-d Indirect immunofluorescence with the MoAb 345.134S on cryostat sections of lung adenocarcinoma (a), intradermal nevus (b), primary nodular melanoma (c), and metastatic melanoma (d). Staining is observed at the plasma membrane of these lesions. a, $\mathbf{c}$, and d $\times 400 ; \mathbf{b} \times 1,000$ 
Table 1. Reactivity of MoAb $345.134 \mathrm{~S}$ with normal adult and tumor tissues assessed by indirect immunofluorescence ${ }^{\mathrm{a}}$

\begin{tabular}{|c|c|c|c|c|}
\hline Group & Normal tissues & Reactivity & Tumors & $\begin{array}{l}\text { No. positive/ } \\
\text { no. tested }\end{array}$ \\
\hline \multirow[t]{5}{*}{ Group 1} & Melanocytes & Negative & Melanoma & $21 / 25$ \\
\hline & Mammary gland & Negative & Breast adenocarcinoma & $9 / 15$ \\
\hline & Lung & Negative & $\begin{array}{l}\text { Lung adenocarcinoma, squamous cell } \\
\text { carcinoma, small cell carcinoma }\end{array}$ & $4 / 5$ \\
\hline & Brain cortex & Negative & Mixed brain tumors & $1 / 10$ \\
\hline & Liver & Negative & Liver adenocarcinoma & $0 / 2$ \\
\hline \multirow[t]{8}{*}{ Group 2} & Skin & & & \\
\hline & $\begin{array}{l}\text { Pigmented (epithelium of } \\
\text { sebaceous glands and basal layer) }\end{array}$ & Positive & $\begin{array}{l}\text { Skin basal cell and squamous } \\
\text { cell carcinoma }\end{array}$ & $7 / 7$ \\
\hline & Non-pigmented (basal cell layer) & $\begin{array}{l}\text { Positive } \\
\text { (weak) }^{b}\end{array}$ & & \\
\hline & Gastrointestinal tract & $\begin{array}{l}\text { Positive } \\
\text { (weak) }\end{array}$ & $\begin{array}{l}\text { Gastric and colonic } \\
\text { adenocarcinoma }\end{array}$ & $\begin{array}{c}7 / 13 \\
\text { (weak) }\end{array}$ \\
\hline & Urinary bladder & $\begin{array}{l}\text { Positive } \\
\text { (weak) }\end{array}$ & $\begin{array}{l}\text { Urinary bladder transitional cell } \\
\text { carcinoma }\end{array}$ & $2 / 3$ \\
\hline & Renal proximal tubules & Positive & Wilms' adenocarcinoma & $1 / 3$ \\
\hline & Parotid & $\begin{array}{l}\text { Positive } \\
\text { (weak) }\end{array}$ & $\begin{array}{l}\text { Parotid mixed cell type } \\
\text { tumor and Warthin's tumor }\end{array}$ & $1 / 2$ \\
\hline & Thyroid & $\begin{array}{l}\text { Positive } \\
\text { (weak) }\end{array}$ & Thyroid adenocarcinoma & $1 / 2$ \\
\hline
\end{tabular}

${ }^{a}$ Cryostat sections were used as substrates for antibodies

${ }^{b}$ Required oil immersion objective to visualize staining

Table 2. Reactivity of a panel of human cell lines in a ${ }^{125} \mathrm{I}$ radioimmunometric binding assay with monoclonal antibodies to cell-surface markers

\begin{tabular}{|c|c|c|c|c|c|c|}
\hline \multirow[t]{2}{*}{ Cell line } & \multicolumn{6}{|c|}{ cpm ${ }^{125} \mathrm{I}-\mathrm{SpA}$ bound } \\
\hline & $\begin{array}{l}\text { MoAb 345.134S } \\
\text { (anti-85K/30K) }\end{array}$ & $\begin{array}{l}\text { MoAb 376.96S } \\
\text { (anti-94K) }\end{array}$ & $\begin{array}{l}\text { MoAb 225.28S } \\
(\text { anti-280K/>440K) }\end{array}$ & $\begin{array}{l}\text { MoAb W6/32 } \\
\text { (anti-HLA-A,B,C) }\end{array}$ & $\begin{array}{l}\text { MoAb NAMB-1 } \\
\left(\text { anti- } \beta_{2}-\mu\right)\end{array}$ & $\begin{array}{l}\text { MoAb Q5/13 } \\
\text { (anti-Ia-like) }\end{array}$ \\
\hline \multicolumn{7}{|l|}{ Melanoma } \\
\hline $\begin{array}{l}\text { Colo38 } \\
\text { M14 } \\
\text { M21 }\end{array}$ & $\begin{array}{r}9,400 \\
30,000 \\
10,000\end{array}$ & $\begin{array}{l}5,000 \\
9,500 \\
2,300\end{array}$ & $\begin{array}{l}33,000 \\
15,800 \\
38,500\end{array}$ & $\begin{array}{r}11,100 \\
14,000 \\
9,500\end{array}$ & $\begin{array}{l}23,000 \\
21,000 \\
16,800\end{array}$ & $\begin{array}{r}13,600 \\
1,000 \\
3,300\end{array}$ \\
\hline \multicolumn{7}{|l|}{ Carcinoma } \\
\hline $\begin{array}{l}\text { Mano } \\
\text { (urinary } \\
\text { bladder) }\end{array}$ & 18,300 & 8,300 & $<500$ & 5,100 & 10,000 & $<500$ \\
\hline $\begin{array}{l}\text { D98 } \\
\text { (cervix) }\end{array}$ & 18,000 & $<500$ & $<500$ & 1,000 & 4,700 & $<500$ \\
\hline $\begin{array}{l}\text { DU } 145 \\
\text { (prostate) }\end{array}$ & 8,000 & 4,000 & $<500$ & 2,600 & $\mathrm{NT}^{\mathrm{a}}$ & $<500$ \\
\hline \multicolumn{7}{|l|}{ Lymphoid } \\
\hline $\begin{array}{l}1301 \\
\text { (T cell) }\end{array}$ & 5,700 & $<500$ & $<500$ & 12,000 & 14,500 & $<500$ \\
\hline $\begin{array}{l}\text { Raji } \\
\text { (B cell) }\end{array}$ & 4,700 & $<500$ & $<500$ & 4,500 & NT & 8,500 \\
\hline $\begin{array}{l}\text { Wil-2 } \\
\text { (B cell) }\end{array}$ & 6,200 & $<500$ & $<500$ & 10,300 & NT & 20,000 \\
\hline
\end{tabular}

${ }^{\mathrm{a}} \mathrm{NT}=$ not tested 
Table 3. Reactivity of the MoAb 345.134 S with cultured human cells in binding and lytic assays

\begin{tabular}{|c|c|c|c|}
\hline Cell line & $\begin{array}{l}{ }^{125} \mathrm{I} \text {-Binding } \\
\text { assay }(\mathrm{cpm})\end{array}$ & $\begin{array}{l}\text { Complement- } \\
\text { dependent } \\
\text { cytotoxicity } \\
\text { (reciprocal } \\
\text { titer) }\end{array}$ & $\begin{array}{l}\text { ADCC } \\
\text { \% specific } \\
\text { release }\end{array}$ \\
\hline \multicolumn{4}{|l|}{ Melanoma } \\
\hline Bw5 & 25,000 & $1 \times 10^{5}$ & 18.3 \\
\hline Colo38 & 12,000 & $1 \times 10^{5}$ & 35.4 \\
\hline M21 & 8,500 & $1 \times 10^{5}$ & 15.4 \\
\hline \multicolumn{4}{|l|}{ Carcinoma } \\
\hline MANO (bladder) & 18,300 & $2 \times 10^{3}$ & 20.4 \\
\hline T24 (bladder) & 16,000 & $1 \times 10^{4}$ & ND \\
\hline \multicolumn{4}{|l|}{ B-lymphoid } \\
\hline Daudi & 4,000 & $1 \times 10^{5}$ & 10.6 \\
\hline Raji & 4,700 & $1 \times 10^{5}$ & 41.3 \\
\hline WI-L2 & 6,200 & $1 \times 10^{5}$ & 40.6 \\
\hline \multicolumn{4}{|l|}{ T-lymphoid } \\
\hline 1301 & 5,700 & $1 \times 10^{5}$ & 15.5 \\
\hline \multicolumn{4}{|l|}{ Myeloid } \\
\hline K562 & 7,000 & $1 \times 10^{5}$ & 42.9 \\
\hline
\end{tabular}

kidneys, the staining was limited to the plasma membrane and the cytoplasm of the epithelium of proximal tubules; (d) the reactivity pattern of tissues from a 20 -week-old fetus is similar to that of normal adult tissues; (e) although normal melanocytes in sections of normal pigmented and hyperpigmented skin were unreactive with the MoAb 345.134S, the majority of intradermal (4 out of 6 cases) and compound ( 7 out of 8 cases) nevic cells exhibited plasma membrane fluorescence, while six blue nevi were unreactive; (f) all the types of tumors tested with the exception of liver adenocarcinomas reacted strongly with the MoAb 345.134S. However, there were some cases within each tumor group that were negative.

In addition to tissue sections, the MoAb 345.134S also reacted with $\mathrm{T}$ and $\mathrm{B}$ lymphocytes, monocytes, and granulocytes from the peripheral blood of healthy donors and with chronic lymphocytic and acute myelogenous leukemic cells in the ${ }^{125}$ I-binding assay; on the other hand, human erythrocytes were unreactive with the monoclonal antibody.

\section{Lytic Activity of the MoAb 345.134S in Complement- and Cell-dependent Cytotoxicity of Cultured Human Cells}

The MoAb $345.134 \mathrm{~S}$ reacts in the ${ }^{125} \mathrm{I}-\mathrm{SpA}$ radioimmunometric assay with a variety of cell lines which include melanoma, carcinoma and lymphoid cell

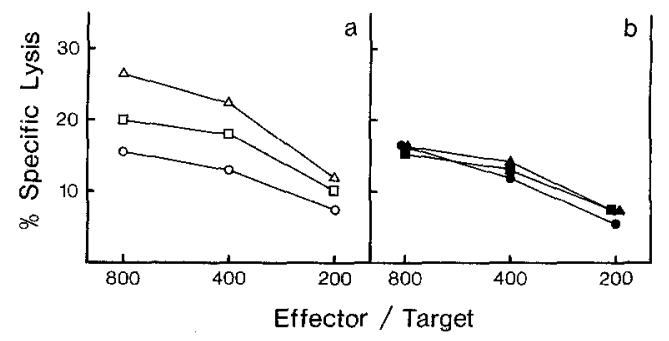

Fig. 4. $\mathbf{a}$ and $\mathbf{b}$ Effect of puromycin and interferon on cell-dependent lysis mediated by MoAb 345.134S. Microtiter plates (each with 96 wells) containing $4 \times 10^{351} \mathrm{Cr}$-labelled melanoma M21 cells previously treated for $18 \mathrm{~h}$ with puromycin $1 \mu \mathrm{g} / \mathrm{ml}(\Delta-\Delta)$ and $0.1 \mu \mathrm{g} / \mathrm{ml}(\square-\square)$ or with human leukocyte interferon $1,000 \mathrm{IU} / \mathrm{ml}$ $(\boldsymbol{\Delta}-\mathbf{\Delta})$ and $500 \mathrm{IU} / \mathrm{ml}(\mathbf{\square}-\mathbf{\square})$ were incubated with $\mathrm{MoAb}$ $345.134 \mathrm{~S}$ prior to addition of murine $\mathrm{C}_{3} \mathrm{H} / \mathrm{HeN}$ splenocytes. Melanoma cells incubated in medium alone (open and closed circles) were used as controls. After $18 \mathrm{~h}$ incubation at $37^{\circ} \mathrm{C}$, the supernates were harvested and counted in a gamma counter, after which the $\%{ }^{51} \mathrm{Cr}$ release was determined as described in Materials and Methods

types. There is no relationship between the level of expression of the antigenic determinant recognized by the MoAb 345.134S and other surface markers tested (Table 2), i.e., HLA-A,B antigens, Ia-like antigens, a $94 \mathrm{~K}$ glycoprotein recognized by the MoAb 376.96S, and a high, molecular-weight glycoprotein recognized by the MoAb 225.28S. Furthermore, the reactivity of the MoAb 345.134S with the cell lines Daudi and with our K562 cells, both of which lack $\beta_{2}-\mu[23,32]$, is in agreement with immunochemical evidence that the structure detected by MoAb 345.134S in the SpA-radioimmunometric assay is not associated with $\beta_{2}-\mu$ and does not require $\beta_{2}-\mu$ for its expression. The level of antigen detectable on melanoma cells with the MoAb 345.134S is not affected by treatment with human leukocyte interferon $(500-2,000 \mathrm{IU} / \mathrm{ml})$, but is reduced by treatment with puromycin $(5 \mu \mathrm{g} / \mathrm{ml})$ (data not shown). The MoAb $345.134 \mathrm{~S}$ can mediate complement- and cell-dependent lysis of cultured human cells (Table 3). The degree of lysis in both assays does not show a relationship with the extent of binding of the MoAb $345.134 \mathrm{~S}$ to the target cells. Furthermore, cultured cells display an increased susceptibility to cell-dependent lysis mediated by the MoAb $345.134 \mathrm{~S}$ following treatment with doses of puromycin $(1 \mu \mathrm{g} / \mathrm{ml})$ which do not affect the level of expression of the target antigen (Fig. 4). On the other hand, no change in the extent of cell-dependent lysis occurs when melanoma cells have been treated with interferon (Fig. 4). 


\section{Discussion}

Immunochemical analysis of the specificity of the MoAb 345.134S has shown that it identifies a two-chain structure composed of an $85 \mathrm{~K}$-dalton glycopolypeptide disulfide-bridged to a $30 \mathrm{~K}$-dalton polypeptide having little if any covalently attached carbohydrate. It is not yet known whether one or both chains carry the antigenic determinant detected by $\mathrm{MoAb}$ 345.134S. Solubilization under various conditions showed that the antigen detected by $\mathrm{MoAb} 345.134 \mathrm{~S}$ is peripheral rather than integral in its association with the plasma membrane.

The MoAb 345.134S was tested with human cell lines in a binding assay and with a large variety of surgically removed normal and malignant tissues in indirect immunofluorescence; the latter assay was preferred to adsorption since it allows identification of the reactive cells. Furthermore, the ability of $\mathrm{MoAb} 345.134 \mathrm{~S}$ to immunoprecipitate the corresponding antigen suggests that it is of high affinity and therefore unlikely to cause binding negative/adsorption positive reactions, which have been reported for certain monoclonal antibodies [6]. Results of this extensive serological analysis of MoAb $345.134 \mathrm{~S}$ show the presence of the antigen in epithelial cells of certain normal fetal and adult tissues and in a large variety of human tumors. In general, the intensity of staining is much stronger for tumor lesions than for their corresponding normal tissues, suggesting that malignant transformation of cells is associated with increased synthesis and/or reduced shedding of this antigen. A variable number of biopsies within each tumor group did not react with MoAb 345.134S. Whether this finding reflects polymorphism of the antigenic determinant defined by the MoAb 345.134S or lack of the antigenic structure in certain tumors is, however, presently unknown. Also, the clinical significance of this differential reactivity of tumors with the MoAb 345.134S cannot be assessed at this time since the number of cases tested is too low and the clinical information is insufficient to draw any firm conclusions.

The antigen detected by MoAb 345.134S appears to be different in its tissue distribution and molecular profile from the several other glycoproteins which have been identified on human cell lines. Some of the most relevant antigens will be compared here. Thus, it is different from the $90 \mathrm{~K}$-dalton glycoprotein described by Judd et al. [15], since this antigen is expressed on dividing cells but is absent from non-dividing cells and monocytes and the molecule exists as a dimer of $200 \mathrm{~K}$ daltons in its native state. It is also different from the $94 \mathrm{~K}$-dalton antigen identified by our MoAb 376.96S [30], the 95K-dalton antigen described by Dippold et al. [6], and the 97K-dalton antigen described by Woodbury et al. [31], since they are single-chain structures and they are mostly restricted to melanomas and carcinomas. The 85K-dalton glycoprotein detected by MoAb $345.134 \mathrm{~S}$ is probably different from a $95 \mathrm{~K}$-dalton glycoprotein isolated from Molt 4 cells [26], since the latter is one of the major glycoproteins synthesized by these cells while our experience suggests that the $85 \mathrm{~K}$ glycoprotein is not so well represented on these cells. Finally, the $85 \mathrm{~K}$-dalton glycoprotein is distinct in tissue distribution from the common ALL antigen described by Sutherland et al. [28] and from the $100 \mathrm{~K}$-dalton glycoprotein found in a variety of different tumors by Bramwell and Harris [4].

The MoAb 345.134S can mediate complementand cell-dependent lysis of human tumor cells. The extent of lysis does not correlate with the level of expression of the antigenic determinant recognized by this monoclonal antibody, indicating that other variables besides antigen density play a significant role in the outcome of immune lytic reactions. This conclusion is also supported by the finding that melanoma cells treated with low doses of puromycin increase in susceptibility to cell-dependent lysis mediated by the MoAb 345.134S, although the level of cell surface target antigen remains unchanged. The amount of antigen detectable by MoAb 345.134S on melanoma cells was also unaffected by doses of interferon that result in increased levels of HLA-A,B,C antigens [12]. This result deserves some comment in view of the reported beneficial effects of interferon on the clinical course of a limited number of melanoma patients [17]. Our experience with monoclonal antibodies to a high-molecular-weight MAA [12] as well as the results here with MoAb 345.134S indicate that the level of expression of tumor-associated antigens as well as the susceptibility of melanoma cells to immune lysis mediated by monoclonal antibodies to these structures are not increased by interferon treatment. These data suggest that if immunological factors play any role in the reported therapeutic effects of interferon on melanoma, they occur by routes other than increased expression of tumor-associated antigens, at least those identified by the monoclonal antibodies we have developed.

Acknowledgements. The work reported in this paper was supported by CNR grants 800159996 and 800151096 and by National Institutes of Health grants AI 19189, CA 32634, CA 24329, and CA 32635. BSW is the recipient of a special fellowship from the Leukemia Society of America.

We wish to acknowledge the excellent technical assistance of Ms. M. R. Nicotra and the secretarial assistance of Ms. Ellen Schmeding. 


\section{References}

1. Allison JP, Belvedere M, Reisfeld RA, Pellegrino MA, Ferrone S (1978) Serologic and immunochemical characterization of HLA-A9 xenoantisera. J Immunol 121: 579

2. Bonner WM, Laskey RA (1974) A film detection method for tritium-labelled proteins and nucleic acids in polyacrylamide gels. Eur J Biochem 46:83

3. Boyum A (1968) Separation of leukocytes from blood and bone marrow. Scand J Clin Lab Invest (Suppl 97) 21:9

4. Bramwell ME, Harris $H$ (1978) An abnormal membrane glycoprotein associated with malignancy in a wide range of different tumors. Proc R Soc Lond [Biol] 201:87

5. Carrel S, Accolla RS, Carmagnola AL, Mach J-P (1980) Common human melanoma associated antigen(s) detected by monoclonal antibodies. Cancer Res 40:2523

6. Dippold WG, Lloyd KO, Li LTC, Ikeda H, Oettgen HF, Old LJ (1980) Cell surface antigens of human malignant melanoma: Definition of six antigenic systems with mouse monoclonal antibodies. Proc Natl Acad Sci USA 77:6114

7. Duksin D, Bornstein P (1976) Impaired conversion of procollagen to collagen by fibtoblasts and bone treated with tunicamycin, an inhibitor of protein glycosylation. $\mathrm{J}$ Biol Chem 252:955

8. Ferrone S, Pellegrino MA (1977) Cytotoxic antibodies to cultured melanoma cells in the sera of melanoma patients. $\mathbf{J}$ Natl Cancer Inst 58: 1201

9. Herlyn M, Clark WH, Mastrangelo MJ, Guerry IV D, Elder DE, La Rossa D, Hamilton R, Bondi E, Tuthill R, Steplewski Z, Koprowski H (1980) Specific immunoreactivity of hybridoma-secreted monoclonal anti-melanoma antibodies to cultured cells and freshly derived human cells. Cancer Res 40:3602

10. Imai K, Molinaro GA, Ferrone S (1980) Monoclonal antibodies to human melanoma-associated antigens. Transplant Proc 12:380

11. Imai K, Ng AK, Ferrone $S$ (1981) Characterization of monoclonal antibodies to human melanoma-associated antigens. J Natl Cancer Inst 66:489

12. Imai $\mathrm{K}, \mathrm{Ng} \mathrm{AK}$, Glassy MC, Ferrone S (1981) Differential effect of interferon on the expression of tumor-associated antigens and histocompatibility antigens on human melanoma cells: Relationship to susceptibility to immune lysis mediated by monoclonal antibodies. J Immunol 127:505

13. Imai $\mathrm{K}, \mathrm{Ng} \mathrm{AK}$, Glassy MA, Ferrone $\mathrm{S}$ (to be published) ADCC of cultured human melanoma cells: Analysis with monoclonal antibodies to human melanoma associated antigens. Scand J Immunol

14. Indiveri F, Huddlestone J, Pellegrino MA, Ferrone S (1980) Isolation of human $\mathrm{T}$ lymphocytes: Comparison between nylon wool filtration and rosetting with neuraminidase (VCN) and 2-aminoethylisothiouronium bromide (AET) treated sheep red blood cells. J Immunol Methods 34: 107

15. Judd W, Poodry CA, Strominger JL (1980) Novel surface antigen expressed on dividing cells but absent from nondividing cells. J Exp Med 152: 1430

16. Koprowski H, Steplewski A, Herlyn D, Herlyn M (1978) Study of antibodies against human melanoma produced by somatic cell hybrids. Proc Natl Acad Sci USA 75:3405
17. Krim M (1980) Towards tumor therapy with interferon. II. Interferon: in vivo effects. Blood 55:875

18. Laemmli UK (1970) Cleavage of structural proteins during the assembly of the head of bacteriophage T4. Nature 227: 680

19. Linder E, Mieltimen A (1976) Prozone effect in indirect immunofluorescence. Scand J Immunol 5:573

20. Mitchell KF, Fuhrer JP, Steplewski Z, Koprowski H (1980) Biochemical characterization of human melanoma cell surfaces: Dissection with monoclonal antibodies. Proc Natl Acad Sci USA 77:7287

21. Natali PG, De Martino C, Quaranta V, Nicotra MR, Frezza F, Pellegrino MA, Ferrone S (1981) Expression of Ia-like antigens in normal human non-lymphoid tissues. Transplantation $31: 75$

22. Natali PG, Imai K, Wilson BS, Bigotti A, Cavaliere R, Pellegrino MA, Ferrone S (1981) Structural properties and tissue distribution of the antigen recognized by the monoclonal antibody $653.40 S$ to human melanoma cells. J Natl Cancer Inst 67:591

23. Ng AK, Pellegrino MA, Imai K, Ferrone S (1981) HLA-A,B antigens, Ia-like antigens and tumor-associated antigens on prostate carcinoma cell lines: Serologic and immunochemical analysis with monoclonal antibodies. J Immunol 127:443

24. Parham P, Barnstable CJ, Bodmer WF (1979) Use of a monoclonal antibody (W6/32) in structural studies of HLA-A,B,C antigens. J Immunol 123: 342

25. Quaranta V, Walker LE, Pellegrino MA, Ferrone S (1980) Purification of immunologically functional subsets of human Ia-like antigens on a monoclonal antibody (Q5/13) immunoadsorbent. J Immunol 125:1421

26. Saito M, Toyoshima S, Osawa T (1978) Isolation and partial characterization of the major sialoglycoprotein of human $\mathrm{T}$ lymphoblastoid cells of a Molt $4 B$ cell line. Biochem $J$ $175: 823$

27. Salisbury JG, Graham JM (1981) Cell-surface radioiodination with the sparingly soluble catalyst Iodogen. Differences between dividing and non dividing rodent thymocytes. Biochem J 194:351

28. Sutherland JJ, Smart P, Niandet P, Greaves M (1978) Acute lymphoblastic leukemia-associated antigen. II. Isolation and partial characterization. Leukemia Res $2: 115$

29. Wilson BS, Imai K, Natali PG, Ferrone S (1981) Distribution and molecular characterization of a cell-surface and a cytoplasmic antigen detectable in human melanoma cells with monoclonal antibodies. Int $\mathrm{J}$ Cancer $28: 293$

30. Wilson BS, Imai K, Natali PG, Kay NE, Cavaliere $R$, Pellegrino MA, Ferrone $S$ (to be published) Immunochemical analysis of the antigenic profile of human melanoma cells with monoclonal antibodies. In; Melanoma antigens and antibodies. Plenum Press, New York

31. Woodbury RG, Brown JP, Loop SM, Hellstrom KE (1981) Analysis of normal neoplastic human tissues for the tumor-associated protein $\mathrm{p} 97$. Int J Cancer 27:145

32. Zeuthen J, Friedrich U, Rosen A, Klein E (1977) Structural abnormalities in chromosome 15 in cell lines with reduced expression of beta-2 microglobulin. Immunogeneties $4: 567$

Received August 6/Accepted October 14, 1981 